\title{
Sphaeropsis sapinea and Water Stress in a Red Pine Plantation in Central Wisconsin
}

\author{
J. T. Blodgett, E. L. Kruger, and G. R. Stanosz
}

First and third authors: Department of Plant Pathology; and second author: Department of Forestry, University of Wisconsin-Madison, 1630 Linden Drive, Madison 53706-1598.

Accepted for publication 22 January 1997.

\begin{abstract}
Blodgett, J. T., Kruger, E. L., and Stanosz, G. R. 1997. Sphaeropsis sapinea and water stress in a red pine plantation in central Wisconsin. Phytopathology 87:429-434.

A study was conducted to determine the effects of water stress resulting from competing vegetation on disease development of Sphaeropsis sapinea in red pine plantations. A 9-year-old plantation was selected in 1992 and experiments were conducted for three consecutive years. Four treatments were assigned at random to individual trees: no treatment, herbicide to kill surrounding weeds, supplemental water, and both herbicide and supplemental water. Two isolates of each S. sapinea morphotype

site at which necrotic needles were observed. Nonwatered trees with competing vegetation (nontreated condition) had significantly lower predawn needle water potentials (more water stress) and more severe disease development than trees that received the herbicide, water, or combined herbicide and water treatments. The most severe disease occurred in the driest year and the least in the wettest year. Competing vegetation indirectly affected disease development by inducing water stress, even in relatively moist years, on trees previously considered well established. Isolates of morphotype A were more aggressive than isolates of morphotype B. Conclusions from this research have implications for sustainable management of the region's conifer forests.
\end{abstract} (A and B) were used to inoculate wounded lateral shoots. Disease development was measured as the maximum distance below the inoculation
Additional keywords: Diplodia pinea, drought, predisposition.
Sphaeropsis shoot blight and canker, caused by Sphaeropsis sapinea (Fr.:Fr.) Dyko \& Sutton in Sutton (syn. Diplodia pinea (Desmaz.) J. Kickx fil.), has caused extensive damage to conifers throughout the world. Pines are affected from the seedling stage to mature size and damage occurs in nurseries, plantations, Christmas tree and ornamental plantings, and natural stands $(7,14,22)$. In the United States, some of the greatest damage caused by $S$. sapinea has occurred on red pine in the Great Lakes region $(21,22,24)$.

Field studies have associated losses caused by $S$. sapinea with predisposing stresses, including drought $(21,23,30)$. In a survey by Nicholls and Ostry (21) of stressed red and jack pine trees in Minnesota and Wisconsin, tree mortality within plots was as high as $30 \%$ for red pine and $51 \%$ for jack pine. In a survey of red pine seedling and sapling plantations in Wisconsin, mortality was as high as $95 \%$ for seedlings and $30 \%$ for saplings (30). In these surveys, reported reasons for the stresses included drought, poor site, hail, snow, and insects. Such field surveys, however, do not provide information on the quantitative effects of water stress in disease development.

Some controlled studies examining the effects of host water stress on disease development have been conducted in greenhouse and growth chambers using hosts other than red pine $(1,9,18,35)$. In these studies, either extremely low host water potentials $(-3.0 \mathrm{MPa}$ or lower) were used, or results were not analyzed statistically. Shoot colonization was greater on red pine seedlings that experienced only moderate water stress (above $-1.9 \mathrm{MPa}$ ) in a greenhouse and growth chamber study that examined the aggressiveness of $S$. sapinea isolates (4). Colhoun (10), however, has suggested that studies of environmental stress

Corresponding author: J. T. Blodgett; E-mail address: jtb@ plantpath.wisc.edu

Publication no. P-1997-0224-01R

(c) 1997 The American Phytopathological Society under controlled conditions may not reflect trends that occur in the field.

Two S. sapinea morphotypes (A and B) are recognized in the north central United States (25). Morphotype is defined as "a group of morphologically differentiated individuals of a species of unknown or of no taxonomic significance" (15). The two $S$. sapinea morphotypes differ in colony morphology and growth rates on potato dextrose agar (25), and aggressiveness on red pine in a greenhouse study (3).

The objectives of this study were to determine whether competing vegetation affects disease development by $S$. sapinea, and if the morphotypes differ in aggressiveness on red pine under field conditions. Host water potential was manipulated by herbicide applications to control competing vegetation and by supplemental water. The null hypotheses were (i) competing vegetation does not affect red pine growth or colonization by $S$. sapinea, (ii) the effect of competing vegetation on disease development is not associated with water stress, and (iii) the two morphotypes of $S$. sapinea produce similar disease severity on red pine under field conditions.

\section{MATERIALS AND METHODS}

Plots were established in a 9-year-old red pine plantation in northern Adams County, central Wisconsin, in early July and maintained for three consecutive years (1992 to 1994) in the same stand. A total of 40 trees were selected in 1992 and the same trees were used in 1993. To avoid any effect of repeated branch removal, a new set of 40 trees was selected in 1994. Trees were selected for uniform height $(1.93 \mathrm{~m} \pm 0.03$ [standard error] in $1992 ; 2.43 \mathrm{~m} \pm 0.03$ in 1994), competing vegetation (ground cover of $88 \% \pm 2$ in 1992; 96\% \pm 1 in 1994), and tree health. A minimal spacing of $4.9 \mathrm{~m}$ occurred between selected trees and trees were located at least $12.2 \mathrm{~m}$ from the plantation edge. The soil type in the area is Plainfield sand (well-drained 
to excessively well-drained; containing $89 \% \pm 0.4$ sand and $7 \%$ \pm 0.4 silt $)$.

Four treatments were assigned at random to individual trees: no treatment, herbicide only, water only, and herbicide and water. In early July of each year, the herbicide glyphosate (Monsanto EnviroChem Systems, Inc., St. Louis) was applied in accordance with label directions within a $1.8 \mathrm{~m}$ radius around the experimental trees 3.5 weeks before branches were inoculated. Water (67 liters per tree) was applied within a $0.9 \mathrm{~m}$ radius around sample trees, twice per week. Watering started in mid July, 2 weeks before branches were inoculated.

Total ground cover (percentage of ground area covered by living vegetation) was visually estimated within a $1.8 \mathrm{~m}$ radius around sample trees before and 2 weeks after the herbicide treatment in all 3 years. Species composition (ground cover of each species as a percentage of total ground cover) was visually estimated within a $1.8 \mathrm{~m}$ radius around sample trees. Species composition was recorded in late August of 1993 only.

Predawn needle water potentials $\left(\psi_{\mathrm{PD}}\right)$ were measured two to four times per week with a pressure bomb (29). On each day of measurement, one needle fascicle from a noninoculated lower branch on each of several randomly selected trees was used for determination of $\psi_{\mathrm{PD}}$. Four trees per treatment were used in 1992, six in 1993, and seven in 1994.

Two A and two B morphotype isolates of $S$. sapinea (Table 1), as well as a wounded and a nonwounded control, were evaluated in this study. Each of the six treatments were assigned randomly to a branch on each tree in late July of each year. Monoconidial isolates of $S$. sapinea used in this study were the same as used in a previous study (3). A wound, $3 \times 1.5 \mathrm{~mm}$, was made by removal of a needle fascicle with a scalpel cut flush to the stem base, approximately $3 \mathrm{~cm}$ below the shoot apex. A plug of colonized 1.5\% water agar (WA) (Difco Laboratories, Detroit) 4 $\mathrm{mm}$ in diameter was placed fungus-side-down on wounds. A noncolonized WA plug was applied to wounded controls. Parafilm (American National Can Co., Chicago) was wrapped around shoots for 7 days.

Symptom severity was measured in late August and was evaluated as the maximum distance below the inoculation site at which necrotic needles were observed 4 weeks after inoculation. After needles were removed, 25 -cm-long shoots were surface disinfected for $10 \mathrm{~s}$ in $95 \%$ ethanol followed by $4 \mathrm{~min}$ in $1.05 \% \mathrm{NaOCl}$ solution with two drops of Tween 80 (Fisher Scientific Co., Toronto, Ontario, Canada) per liter. A small piece of each shoot segment, centered at the site of inoculation, was cut aseptically to determine recovery success of $S$. sapinea. These pieces were placed in individual slants containing 2\% WA and incubated for 3 months at ambient laboratory temperature (approximately $23^{\circ} \mathrm{C}$ ) and light. The presence of $S$. sapinea in incubated pieces was determined by examining the resulting mycelia, pycnidia, and conidia.

Stem diameters at $0.3 \mathrm{~m}$ and tree heights were measured in mid-July of 1992 to 1995 . Percentage growth was calculated as follows: percentage of growth $=[($ final size - initial size $) /$ initial size $] \times 100$. Final stem diameters and tree heights were determined after 1 year. Percentage of growth was used to standardize growth among trees that had different initial sizes. Precipitation was not recorded at the study site in 1992, but was

TABLE 1. Origin of Sphaeropsis sapinea isolates used in a field study in central Wisconsin during 1992 to 1994

\begin{tabular}{lcll}
\hline Isolate $^{\mathrm{a}}$ & Isolate no. $^{\mathrm{b}}$ & \multicolumn{1}{c}{ Host } & \multicolumn{1}{c}{ Geographic origin } \\
\hline A1 & 411 & Pinus resinosa & Clearwater Co., MN \\
A2 & 128 & P. resinosa & Grant Co., WI \\
B1 & 124 & P. banksiana & Jackson Co., WI \\
B2 & 215 & P. resinosa & Douglas Co., WI \\
\hline
\end{tabular}

${ }^{a}$ Morphotype and isolate number.

${ }^{\mathrm{b}}$ Culture collection numbers of M. A. Palmer. recorded at the study site for July and August in 1993 and 1994. Soil temperatures of the top $20 \mathrm{~cm}$ were recorded from the south side of trees used for $\psi_{\mathrm{PD}}$. Temperatures were recorded from 11:30 a.m. to 12:00 p.m. for 3 days in 1992 and 1994, and 5 days in 1993. Climate data were obtained for Hancock, $23 \mathrm{~km}$ east of the study site, from the National Weather Service and the University of Wisconsin Agricultural Weather Station.

Statistical analyses. Symptom severity was analyzed by twofactor analysis of variance with interactions. Factors used as main effects were tree treatment and branch treatment. A split plot model was used with the tree as the whole plot and branches as subplots. The symptom severity data were analyzed both untransformed and after $\ln (x+1)$ transformation was applied. The $P$ values and resulting conclusions were similar for both forms of analysis, therefore, results are reported here only for the untransformed data. Quantitative data for trees (daily $\psi_{\mathrm{PD}}$ and height and diameter growth) were analyzed by one-way analyses of variance with tree treatment as the factor. If significant differences were found $(P \leq 0.05)$, means were separated using Fisher's least significant differences (LSD) at $P=0.05$. Two different LSD values were determined for symptom severity because of the split plot nature of the experimental design (20). Simple linear regression analyses were used to examine relationships between symptom severity and mean $\psi \mathrm{PD}$ and between precipitation recorded at the study site in 1993 and 1994 and precipitation at Hancock. Analyses of variance (using general linear model procedure) and linear regression analyses were performed with the Minitab for Windows program (release 10.2; Minitab Inc., State College, PA).

\section{RESULTS}

Competing vegetation at the study site consisted mainly of grasses or grass-like species. The vegetation was dominated by Pennsylvania sedge (Carex pensylvanica Lam.), which made up $83 \% \pm 3$ (standard error) of the ground cover. Horseweed (Conyza canadensis (L.) Cronq.) was the next most common single species making up $4 \% \pm 1$ of the ground cover. A combination of grass species and other sedges made up $6 \% \pm 3$ of the ground cover. The most common grasses were little bluestem (Andropogon scoparius Michx.), big bluestem (A. gerardii Vitman.), and other prairie grass species typically found in pine barrens and early successional northern dry forests. The remaining $7 \%$ consisted of various woody species and forbs consisting primarily of composites. Indicator species typically found in pine barrens such as American hazelnut (Corylus americana Marsh.), flowering spurge (Euphorbia corollata L.), and wild rose (Rosa sp.) also were present. Unplanted areas surrounding the study site were dominated by jack pine and include other tree and ground cover species (2) typical of northern dry forests (such as Quercus sp., C. americana,

TABLE 2. Total monthly precipitation at Hancock, WI

\begin{tabular}{lcc}
\hline Year/month & Precipitation $(\mathrm{cm})^{\mathrm{a}}$ & Surplus or deficiency $(\mathrm{cm})^{\mathrm{b}}$ \\
\hline 1992 & & \\
June & 4.40 & -4.85 \\
July & 10.57 & +1.43 \\
August & 8.23 & -1.73 \\
1993 & & \\
June & 17.42 & +8.17 \\
July & 21.59 & +12.45 \\
August & 13.54 & +3.58 \\
1994 & & \\
June & 9.42 & +0.17 \\
July & 17.37 & +8.23 \\
August & 9.58 & -0.38 \\
\hline
\end{tabular}

a Precipitation as reported by the National Weather Service.

b The difference between total monthly precipitation and 30-year monthly average (1961 to 1990) at Hancock. 
Prunus sp., Rubus sp., Rosa sp., and C. pensylvanica) that often replace pine barrens.

The herbicide treatment was effective at reducing overall ground vegetation. Initial percentage of cover was $88 \% \pm 2$ in 1992 and $96 \% \pm 1$ in 1994. Since the same trees were used in 1992 and 1993, initial ground covers were $87 \% \pm 4$ for nonherbicide and $7 \% \pm 1$ for the herbicide treatment in 1993 . The herbicide treat- ment reduced ground cover to $3 \% \pm 0.4$ in $1992 ; 1 \% \pm 0.4$ in 1993; and $0.2 \% \pm 0.2$ in 1994 .

Precipitation recorded at the study site in 1993 and 1994 was highly correlated with the precipitation data obtained from the National Weather Service for Hancock ( $r=0.87$ in 1993 and 0.91 in 1994; $P \leq 0.001$ for both years). Precipitation at Hancock was lowest in 1992 and highest in 1993 (Table 2). Among the 3 years,

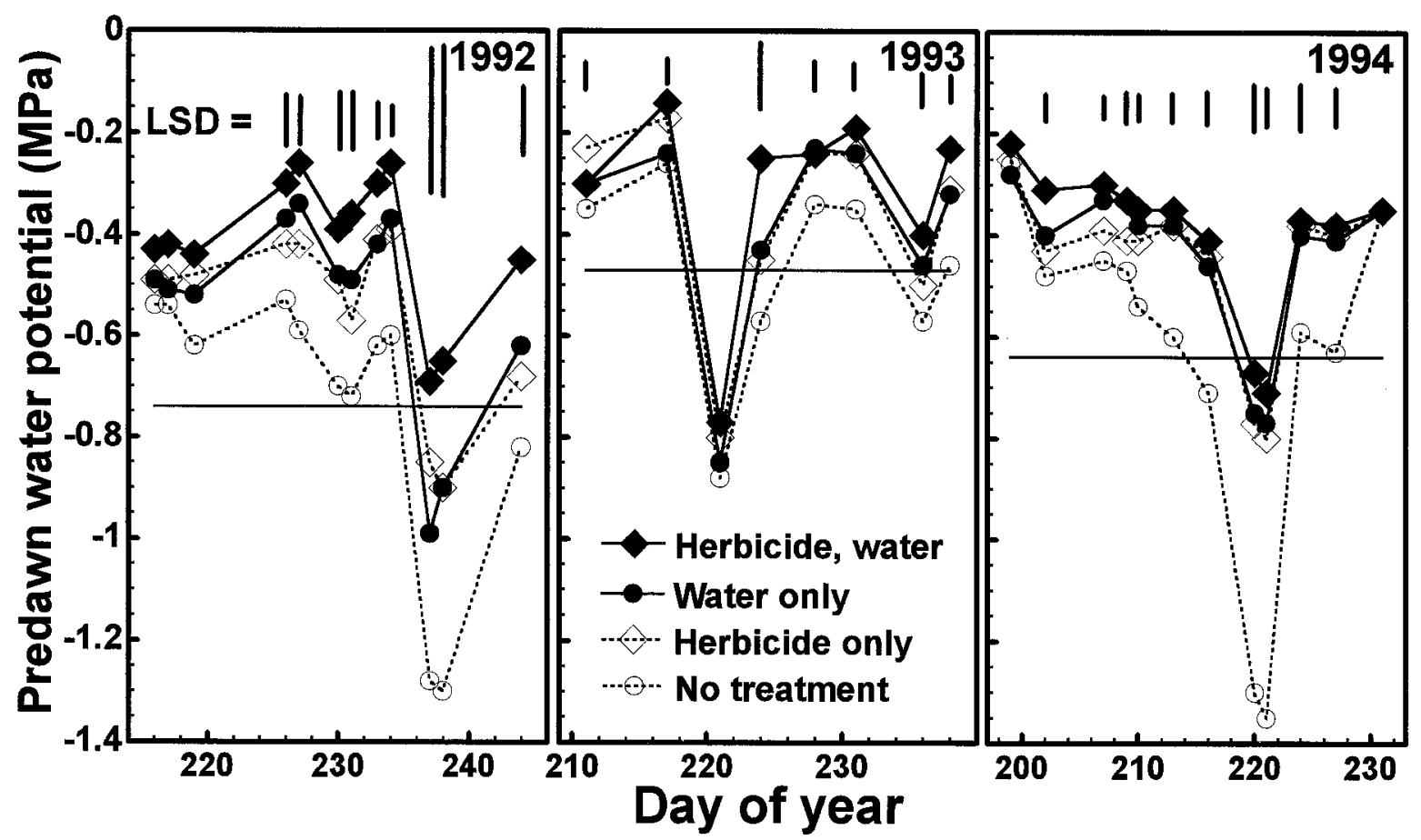

Fig. 1. Mean predawn needle water potentials for red pine (Pinus resinosa) trees by tree treatment. Four trees per treatment were used in 1992 , six in 1993 , and seven in 1994. Vertical lines show Fisher's least significant differences for separating the means for a given day at $P=0.05$. The horizontal line in each panel is the average predawn needle water potential of all nontreated trees (no treatment) in a given year.

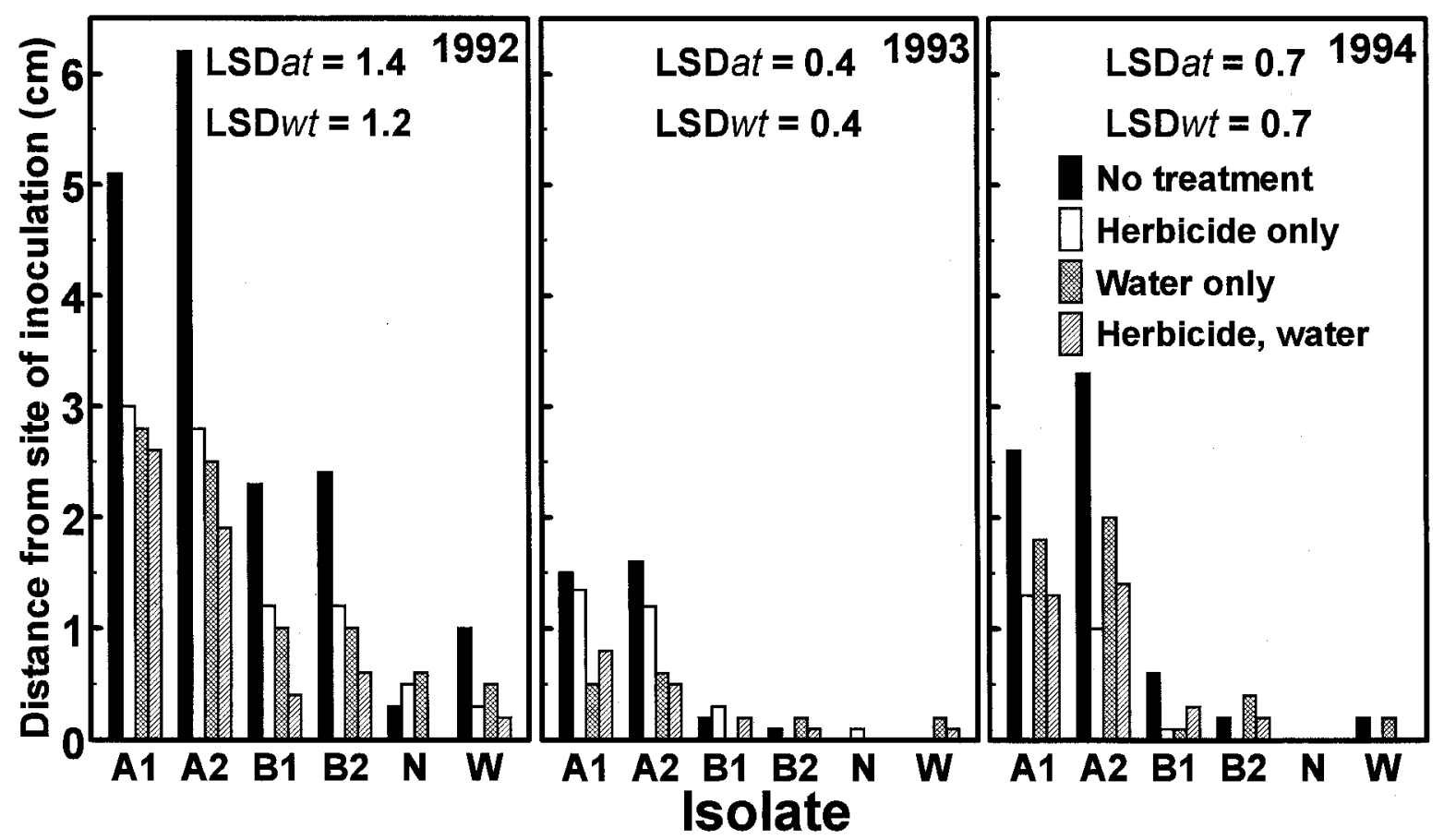

Fig. 2. The average maximum distance below the inoculation site at which necrotic needles were observed on wounded red pine (Pinus resinosa) trees inoculated with agar plugs colonized by Sphaeropsis sapinea isolates of morphotype A and B. Forty trees were used each year, 10 per treatment. Branch treatments include two A (A1 and A2) and two B (B1 and B2) isolates and both nonwounded (N) and wounded (W) controls for each tree. The LSD values are Fisher's least significant differences for separating the means at $P=0.05$. The LSDat is for separating the means of branch treatments across (for different) tree treatments. The LSD wt is for separating the means for branch treatments within the same tree treatment. 
relationships were not apparent between symptom severity and climatic variables measured at Hancock (air temperatures, relative humidity, vapor pressure deficit, wind speed, and total solar radiation) other than precipitation (2).

The mean soil temperature of the top $20 \mathrm{~cm}$ differed among tree treatments $(P<0.001$ in 1993 and 1994; $P=0.050$ in 1992). Higher soil temperatures were measured in herbicide treated plots compared with those not treated with herbicide. However, in none of the 3 years was symptom severity related to soil temperature measured under experimental trees.

There were distinct differences in $\psi_{\mathrm{PD}}$ among years (Fig. 1). Mean $\psi_{\mathrm{PD}}$ of nontreated trees, for all days, were lowest in 1992 $(-0.74 \mathrm{MPa} \pm 0.04)$, followed by $1994(-0.64 \mathrm{MPa} \pm 0.01)$, and highest in $1993(-0.46 \mathrm{MPa} \pm 0.01)$. There also were significant differences in the mean $\psi_{\mathrm{PD}}$ among tree treatments during all 3 years (Fig. $1 ; P<0.001$ for all 3 years). Nontreated trees had consistently lower mean $\psi_{\mathrm{PD}}$ compared with all other tree treatments. The lowest mean $\psi_{\mathrm{PD}}$ of nontreated trees, for a single day, was $-1.30 \mathrm{MPa} \pm 0.10$ in $1992,-0.88 \mathrm{MPa} \pm 0.02$ in 1993 , and -1.35 $\mathrm{MPa} \pm 0.02$ in 1994 .

Distinct differences in symptom severity occurred among years (Fig. 2). The average maximum distance below the inoculation site at which necrotic needles were observed on nontreated trees inoculated with isolates of morphotype A was greatest in 1992 $(5.7 \mathrm{~cm} \pm 0.5)$, followed by $1994(3.0 \mathrm{~cm} \pm 0.4)$, and lowest in $1993(1.6 \mathrm{~cm} \pm 0.2)$. Symptom severity among years was consistent with $\psi_{\mathrm{PD}}$ among years (Figs. 1 and 2).

Distinct differences in symptom severity also occurred among tree treatments and branch treatments (Fig. 2). Trees that received herbicide and water treatments had less severe symptoms than nontreated trees in all 3 years $(P<0.001$ for tree treatments in 1992 and 1994 and $P=0.004$ in 1993). Branches inoculated with isolates of morphotype A had more severe symptoms than branches inoculated with isolates of morphotype B of the same tree treatments $(P<0.001$ for isolates in all 3 years $)$. The interaction between tree treatment and branch treatment was significant $(P=0.012$ in $1992, P<0.001$ in 1993 and 1994), indicating that different isolates responded differently depending on the tree treatment. Differences in symptom severity among tree treatments were only significant for isolates of morphotype A, based on LSD.

Symptom severity and mean $\psi_{\mathrm{PD}}$ (averaged over all days) were negatively correlated for branches inoculated with isolates of morphotype A. For A1: $r=-0.58, P=0.019$ in $1992 ; r=-0.23, P=$ 0.289 in 1993; and $r=-0.62, P<0.001$ in 1994. For A2: $r=-0.77$,

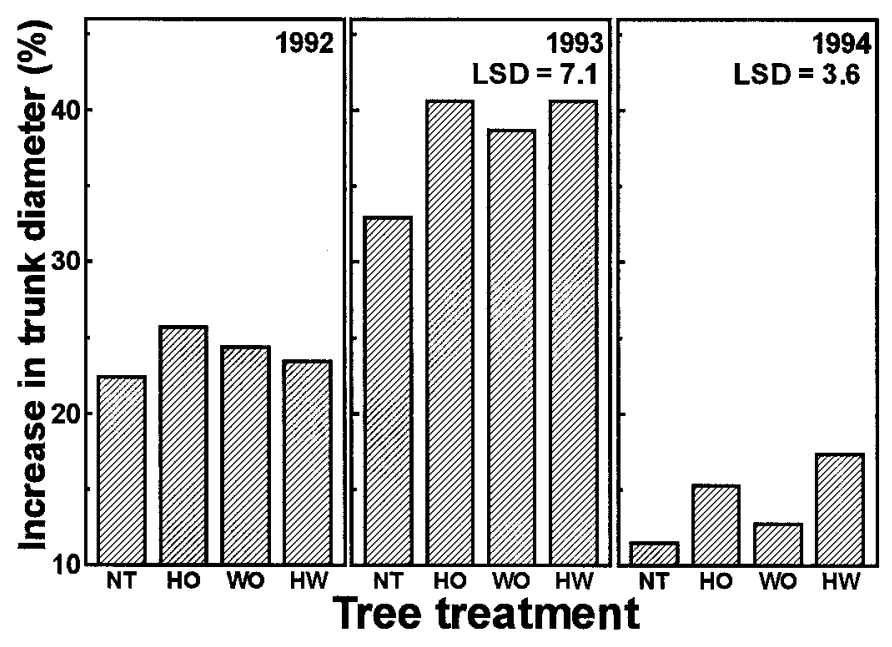

Fig. 3. Percentage of increase in trunk diameter of red pine (Pinus resinosa) trees by tree treatment for the period from 1992 to 1995 . Four treatments were assigned at random to individual trees: no treatment (NT), herbicide only (HO), water only (WO), and herbicide and water (HW). Values are means of 10 trees per treatment. The LSD values are Fisher's least significant differences for separating the means at $P=0.05$.
$P<0.001$ in $1992 ; r=-0.47, P=0.022$ in 1993 ; and $r=-0.59, P$ $=0.002$ in 1994. Correlations were not significant for branches inoculated with isolates of morphotype B.

$S$. sapinea was recovered from branches inoculated with either morphotype. For all tree treatments, isolates of morphotype A were successfully recovered at the inoculation point $68 \% \pm 7$ of the time in $1992,89 \% \pm 5$ in 1993 , and $90 \% \pm 2$ in 1994. For isolates of morphotype B, S. sapinea was successfully recovered at the inoculation point $48 \% \pm 8$ of the time in 1992, $69 \% \pm 7$ in 1993 , and $71 \% \pm 7$ in 1994 . For all controls it was recovered $7 \% \pm 4$ of the time in $1992,4 \% \pm 2$ in 1993 , and $1 \% \pm 1$ in 1994.

Differences in trunk diameters among treatments were not significant when trees were selected $(P=0.911$ in $1992 ; P=0.977$ in 1994). Differences in percentage of growth of trunk diameters among tree treatments were measured for 2 of the 3 years $(P=0.102$ in $1993 ; P=0.011$ in 1994) (Fig. 3). The diameter growth was consistently less for nontreated trees compared with trees that received the herbicide or water treatments. When the same trees were compared, greater diameter growth occurred in the wettest year (1993) than in the driest year (1992). Differences in height growth among tree treatments were not significant in any year.

\section{DISCUSSION}

This study demonstrates the importance of considering both environmental factors and variation within the pathogen population when examining host susceptibility to $S$. sapinea. Environmental predispositions from a variety of sources have been shown to affect woody plant disease severity. These include water and temperature extremes, and defoliation, transplant, soil nutrient, and light stresses $(26,28)$. Increased disease development by $S$. sapinea has been associated with water stress $(1,4,9,18,35)$, high soil nutrition (34), and hail damage $(33,37)$. Temperature and humidity are important factors in infection $(5,8)$. Seasonal variations (32) and climate differences (17) also have been related to differences in the amount of disease caused by $S$. sapinea. The current study shows that competing vegetation and $S$. sapinea morphotype also are important factors to consider when managing pine plantations.

Water stress caused by the competing vegetation appeared to be the dominant factor involved in the increased disease severity observed. Previous field studies that associate losses caused by $S$. sapinea to drought did not demonstrate a clear, quantitative relationship between host water stress and colonization by the pathogen $(21,23,30)$. In the current study, the yearly differences in symptom severity were consistent with differences in precipitation, $\psi_{\mathrm{PD}}$ data, and reductions in symptom severity due to watering. However, severity of water stress due to competition is also an important factor as indicated by reduction in symptom severity on trees treated with herbicide in the two driest years. Although higher soil temperatures were measured under the herbicide trees compared with nonherbicide trees, soil temperatures did not explain differences in symptom severity on trees that received water only and not the herbicide treatment. Therefore, water availability is likely involved in the differences in aggressiveness of $S$. sapinea both among years and among treatments.

The observed effects of competition on tree water relations and growth are consistent with previous reports. Thinned red pine stands have more water in the upper soil during the growing season than do unthinned stands (12,31). Sucoff and Hong (31) also found $\psi_{\mathrm{PD}}$ to be higher in thinned stands. In the southern United States, competing vegetation can affect the water status of southern pines in plantations $(13,19)$. Miller et al. (19) found that competition of both herbaceous and woody vegetation resulted in a significant reduction in height and diameter growth, with herbaceous competition having the greatest effect. Caldwell et al. (6) 
found that grass competition limited resource availability (water, soil nutrients, and light) and resulted in reduced growth of red pine seedlings in Minnesota. In the current study, competing vegetation significantly lowered $\psi_{\mathrm{PD}}$ and resulted in reduced diameter growth and increased disease severity by $S$. sapinea. The observed effect on tree growth is evidence of the reduction of many physiological processes in trees $(16,27)$ that may affect the ability of a host to defend itself (27).

Previous results from greenhouse and growth chamber experiments demonstrating differences in aggressiveness between isolates of morphotype A and B $(3,4)$ and in their response to host stress (4) were confirmed in this field study. Using potted seedlings, Blodgett et al. (4) found significant increases in aggressiveness for morphotype A isolates, but not for isolates of morphotype B when hosts were moderately water stressed $\left(\psi_{\mathrm{PD}}\right.$ at or above $-1.9 \mathrm{MPa}$ ) in a greenhouse and growth chamber study. In that study, neither a discrete threshold level of water potential nor a prolonged water stress were necessary to enhance colonization by $S$. sapinea. The similarity of results from our greenhouse studies adds additional support to our conclusions on the relative aggressiveness of $S$. sapinea morphotypes on red pine and their responses to host water stress.

The red pine plantation used in this study, although representative of many in the region, may not be within an ideal area for sustainable production of red pine. Fire-suppression practices, fragmentation of land by constructing roads and farming, and the sandy-dry-infertile soil at this site tends to favor jack pine over red pine (11). Studies of the early vegetation of Wisconsin classified this area as a pine barren composed of jack pine and prairie grasses (11). Vegetation in the plantation and surrounding vegetation would categorize the study site as a jack pine forest or jack pine barren $(11,36)$. Establishment of red pine on a site for which it was not well adapted may have contributed to the water stress observed in this study.

Because isolates of morphotype $\mathrm{A}$ are more aggressive than isolates of morphotype $\mathrm{B}$, identification of the morphotype(s) in a plantation may provide some indication of risk of damage from this disease and may help to determine if management is required to control the disease in an area. Water stress at levels observed for short periods in wet years and at levels typically observed during any year (above $-1.7 \mathrm{MPa}$ ), can result in greater disease development by $S$. sapinea morphotype A on red pine. Competing vegetation has substantial effects on water status, even in relatively wet years, on trees previously considered well established. Therefore, planting on drought-prone sites should be avoided. If planting on drought-prone sites, reducing water stress is an important factor in controlling Sphaeropsis shoot blight. Management of competing vegetation, stand thinning, planting techniques that reduce drought, and selection of a tree species compatible with a site should reduce losses due to Sphaeropsis shoot blight and foster sustainable use of forest resources.

\section{ACKNOWLEDGMENTS}

We thank USDA (Hatch) and Georgia-Pacific Corporation for partial financial support. We thank J. Buck for presubmission review, K. Johnson and three anonymous reviewers for their many helpful suggestions, M. Clayton for statistical advice, and M. Palmer for cultures. We also thank D. Maxwell, D. Smith, M. Guthmiller, F. Kirschling, G. Sandhu, D. Feller, and L. Covert for technical assistance, and J. Trobaugh, J. Cappel, and J. Bagley from Georgia-Pacific Corporation.

\section{LITERATURE CITED}

1. Bachi, P. R., and Peterson, J. L. 1985. Enhancement of Sphaeropsis sapinea stem invasion of pines by water deficits. Plant Dis. 69:798-799.

2. Blodgett, J. T. 1996. The Effects of Host Water Stress on Disease Development by Different Sphaeropsis sapinea Morphotypes. Ph.D. dissertation. University of Wisconsin-Madison, Madison.
3. Blodgett, J. T., and Stanosz, G. R. 1997. Sphaeropsis sapinea morphotypes differ in aggressiveness, but both infect nonwounded red or jack pines. Plant Dis. 81:143-147.

4. Blodgett, J. T., Kruger, E. L., and Stanosz, G. R. 1997. Effects of moderate water stress on disease development by Sphaeropsis sapinea on red pine. Phytopathology 87:397-403.

5. Brookhouser, L. W., and Peterson, G. W. 1971. Infection of Austrian, Scots, and ponderosa pine by Diplodia pinea. Phytopathology 61:409414.

6. Caldwell, J. M., Sucoff, E. I., and Dixon, R. K. 1995. Grass interference limits resource availability and reduces growth of juvenile red pine in the field. New For. 10:1-15.

7. Chou, C. K. S. 1976. A shoot dieback in Pinus radiata caused by Diplodia pinea. I. Symptoms, disease development and isolation of pathogen. N.Z. J. For. Sci. 6:72-79.

8. Chou, C. K. S. 1982. Susceptibility of Pinus radiata seedlings to infection by Diplodia pinea as affected by pre-inoculation condition. N.Z. J. For. Sci. 12:438-441.

9. Chou, C. K. S. 1987. Crown wilt of Pinus radiata associated with Diplodia pinea infection of woody stems. Eur. J. For. Pathol. 17:398411.

10. Colhoun, J. 1973. Effect of environmental factors on plant disease. Annu. Rev. Phytopathol. 11:343-364.

11. Curtis, J. T. 1987. The Vegetation of Wisconsin: An Ordination of Plant Communities. The University of Wisconsin Press, Madison.

12. DeVries, M. L., and Wilde, S. A. 1962. Effect of the density of red pine stands on moisture supply in sandy soil. Neth. J. Agric. Sci. 10:235-239.

13. Fredericksen, T. S., Allen, H. L., and Wentworth, T. R. 1991. Competing vegetation and pine growth response to silvicultural treatments in a sixyear-old Piedmont loblolly pine plantation. South. J. Appl. For. 15:138144.

14. Gibson, I. A. S. 1979. Diseases of Forest Trees Widely Planted as Exotics in the Tropic and Southern Hemisphere. Part II. The Genus Pinus. Commonwealth Mycological Institute, Kew, England.

15. Hawksworth, D. L., Kirk, P. M., Sutton, B. C., and Pegler, D. N. 1995. Ainsworth and Bisby's Dictionary of the Fungi, 8th ed. International Mycological Institute, Egham, England.

16. Kozlowski, T. T., ed. 1976. Water Deficits and Plant Growth, Vol. 4. Academic Press, New York.

17. Lundquist, J. E. 1987. A history of five forest diseases in South Africa. S. Afr. For. J. 140:51-59.

18. Madar, Z., Solel, Z., and Kimchi, M. 1989. Effect of water stress in cypress on the development of cankers caused by Diplodia pinea f. sp. $\mathrm{cu}$ pressi and Seiridium cardinale. Plant Dis. 73:484-486.

19. Miller, J. H., Zutter, B. R., Zedaker, S. M., Edwards, M. B., Haywood, J. D., and Newbold, R. A. 1991. A regional study on the influence of woody and herbaceous competition on early loblolly pine growth. South. J. Appl. For. 15:169-179.

20. Milliken, G. A., and Johnson, D. E. 1993. Analysis of Messy Data. Vol. 1. Designed Experiments. Chapman and Hall, London.

21. Nicholls, T. H., and Ostry, M. E. 1990. Sphaeropsis sapinea cankers on stressed red and jack pines in Minnesota and Wisconsin. Plant Dis. 74:54-56.

22. Nicholls, T. H., Ostry, M. E., and Prey, A. J. 1977. Diplodia pinea pathogenic to Pinus resinosa. (Abstr.) Proc. Am. Phytopathol. Soc. 4:110.

23. Palmer, M. A. 1991. Isolate types of Sphaeropsis sapinea associated with main stem cankers and top-kill of Pinus resinosa in Minnesota and Wisconsin. Plant Dis. 75:507-510.

24. Palmer, M. A., and Nicholls, T. H. 1985. Shoot blight and collar rot of Pinus resinosa caused by Sphaeropsis sapinea in forest tree nurseries. Plant Dis. 69:739-740.

25. Palmer, M. A., Stewart, E. L., and Wingfield, M. J. 1987. Variation among isolates of Sphaeropsis sapinea in the north central United States. Phytopathology 77:944-948.

26. Schoeneweiss, D. F. 1975. Predisposition, stress, and plant disease. Annu. Rev. Phytopathol. 13:193-211.

27. Schoeneweiss, D. F. 1978. Water stress as a predisposing factor in plant disease. Pages 61-99 in: Water Deficits and Plant Growth, Vol. 5. T. T. Kozlowski, ed. Academic Press, New York.

28. Schoeneweiss, D. F. 1981. The role of environmental stress in diseases of woody plants. Plant. Dis. 65:308-314.

29. Scholander, P. F., Hammel, H. T., Edda, D., Bradstreet, E. D., and Hemmingsen, E. A. 1965. Sap pressure in vascular plants. Science 148:339-346.

30. Stanosz, G. R., and Cummings Carlson, J. 1996. Association of mortality of recently planted seedlings and established saplings in red pine plantations with Sphaeropsis collar rot. Plant Dis. 80:750-753.

31. Sucoff, E., and Hong, S. G. 1974. Effect of thinning on needle water potential in red pine. For. Sci. 20:25-29.

32. Swart, W. J., and Wingfield, M. J. 1991. Seasonal response of Pinus 
radiata in South Africa to artificial inoculation with Sphaeropsis sapinea. Plant Dis. 75:1031-1033.

33. Swart, W. J., Wingfield, M. J., and Knox-Davies, P. S. 1987. Factors associated with Sphaeropsis sapinea infection of pine trees in South Africa. Phytophylactica 19:505-510.

34. Van Dijk, H. F. G., Van Der Gaag, M., Perik, P. J. M., and Roelofs, J. G. M. 1992. Nutrient availability in Corsican pine stands in the Netherlands and the occurrence of Sphaeropsis sapinea: A field study. Can. J. Bot. 70:870-875.
35. Wattermann, J. L., Gleason, M. L., Bradford, E., Iles, J. K., and Flynn, P. H. 1993. Effect of preinoculation and postinoculation water stress on stem invasion of Scots pine by Sphaeropsis sapinea. (Abstr.) Phytopathology 83:1410.

36. Wilkinson, R. E., and Jaques, H. E. 1972. The Weeds. W. C. Brown Company Publishers, Dubuque, IA.

37. Zwolinski, J. B., Swart, W. J., and Wingfield, M. J. 1990. Economic impact of a post-hail outbreak of dieback induced by Sphaeropsis sapinea. Eur. J. For. Pathol. 20:405-411. 